\title{
Evaluation of Sugarcane Genotypes for Morphological and Quality Traits under Water Logging Conditions
}

\author{
Vikas Belwal* and Sarfraz Ahmad \\ Department of Genetics and Plant Breeding, G.B. Pant University of Agriculture and \\ Technology, Pantnagar, Uttarkhand - 263 145, India \\ *Corresponding author
}

\begin{tabular}{|l|}
\hline Ke y w o r d s \\
Evaluation, \\
Morphological \\
traits, Quality traits, \\
$\begin{array}{l}\text { Sugarcane, Water } \\
\text { logging }\end{array}$ \\
\hline Article Info \\
\hline $\begin{array}{l}\text { Accepted: } \\
\text { 08 January } 2020 \\
\text { Available Online: } \\
\text { 10 February } 2020\end{array}$ \\
\hline
\end{tabular}

\section{A B S T R A C T}

The present investigation was carried out with eighteen clones including four water logging tolerant checks at the Sugarcane Breeding Experimental Block of Norman Borlaug Crop Research Centre, Gobind Ballabh Pant University of Agriculture and Technology, Pantnagar, India. Genetic variability was studied for thirteen different morphological and quality parameters viz., germination percent, number of tillers, number of millable canes, cane height, cane thickness, cane weight, cane yield, CCS yield, juice brix, sucrose \%, purity $\%, \mathrm{CCS} \%$ and juice extraction percent. Analysis of variance revealed significant differences among all the genotypes for all characters studied. Three genotypes or clones namely CoS 767, CoPant 90223 and CoPant 3220 had high number of millable canes than the check CoSe 96436 and found at par with other three checks. The clones CoS 767 and CoPant 90223 were superior than all four checks in terms of high sucrose content, purity percent and CCS percent. Juice purity was also recorded high for Co 1148, Cos 767 and CoPant 90223 also had cane and CCS yield at par with the best performing check under water logging conditions. On the basis of cane and quality attributes, the clones namely, CoS 767 and CoPant 90223 were found performing at par as compared to checks. The study also provides information about the performance of some of the promising sugarcane genotypes in respect of morphological and quality characters and identifies some prominent genotypes.

\section{Introduction}

Sugarcane (Saccharum sp. Complex hybrid) is an important cash crop of India and all over the world. Sugar industry is one of the largest agro-processing industries, next only to cotton textiles. About $50 \%$ of sugarcane production occurs in Brazil and India. Sugarcane belongs to family Poaceae, Sub family Panicoidae, tribe Andropogoneae, Sub tribe
Saccharanineae and Genus Saccharum (Watson et al., 1985). It has $2 \mathrm{~N}=80-120$, which vary from species to species. It has basic chromosome number $X=6,8,10$. The cultivated species in India are the interspecies hybrids inheriting genes and characteristics from Saccharum officinarum, Saccharum barberi and Saccharum spontaneum (Rao et al., 1983). 
Sugarcane is grown under different types of soil and water regimes. Being a long duration crop it faces various natural calamities especially biotic/abiotic stresses during its life cycle. In India considerable area under sugarcane is prone to water logging, adversely affecting cane productivity and quality. The sugarcane planted on relatively low land where water remains stagnant for longer period results in poor yield. The yield and quality effects due to water logging depends upon the clones, environmental conditions, stage of development and the duration of stress (Orchard \& Jessop, 1984; Choi et al., 1986). Generally water logging problem coincides with growth phase of sugarcane crop. Higher water table during active growth phase adversely affects stalk weight and plant population leading to reduction of yield about one ton per acre for each one inch increase in excess water (Carter, 1976; Carter and Floyed, 1974). In general water logging induces anaerobic condition in soil. Moreover, excess rainfall during late summer and monsoon quite often creates flooding problem and rears have no options but to use flood affected sugarcane. For development of improved water logging clones, information on the variability on yield and quality characters is needed. In view of the above facts, present investigation was carried out to evaluate the clones/genotypes for morphological and quality traits under water logging condition.

\section{Materials and Methods}

The present investigation was carried out at the Sugarcane Breeding Experimental Block of Norman Borlaug Crop Research Centre, Gobind Ballabh Pant University of Agriculture and Technology, Pantnagar, India, during 2010-2011. The experimental materials were consisted of eighteen clones or genotypes including four water logging tolerant checks viz. CoS 97264, CoSe 96436,
BO 91 and UP 9530. All the genotypes taken were from the different origins and were as CoS 767 (Shahjahanpur), CoPant2218 (Pantnagar), CoPant 90223 (Pantnagar), CoPant 3230 (Pantnagar), CoPant 5222 (Pantnagar), CoPant 97222 (Pantnagar), CoPant 3219 (Pantnagar), CoS 96268 (Shahjahanpur), CoPant 99214 (Pantnagar), Co 1148 (Coimbatore), CoPant 84211 (Pantnagar), CoK 16/05 (Kashipur), CoPant 5224 (Pantnagar), CoJ 64 (Jalandhar). The field experiment was carried out using randomized block design (RBD) with two replications. The plot size for each entry represented 4 rows of 5 meter length spaced at $90 \mathrm{~cm}$ apart. Twenty sets of three buds each were planted in each row. The seed was planted $25-30 \mathrm{~cm}$ deep, at the rate of 4 setts per meter with 3 buds per sett. The crop field was waterlogged twice, first for three days during July 18-20, 2010 at $60 \mathrm{~cm}$ water depth and then for four days from 18 to 21 August, 2010 with the water depth of $69.5 \mathrm{~cm}$.

\section{Observations recorded}

The observations on morphological and quality traits were recorded at the various stages of crop growth as per the standard procedure. Germination percent was recorded after 60 days of planting. Number of tillers and Numbers of millable canes (NMC) were counted on the whole plot basis and converted to per hectare. The observations on cane height (meter), cane thickness $(\mathrm{cm})$, single cane weight $(\mathrm{kg})$ and juice weight $(\mathrm{kg})$ were recorded on five representative canes and mean was calculated. Cane yield in $\mathrm{kg}$ per plot was determined by multiplying the number of millable canes (NMC) with average cane weight (i.e. single cane weight) and later was converted into tonnes per hectare. The commercial cane sugar yield (CCS yield) tonnes per hectare were calculated by multiplying CCS percent (at harvesting time in plant and ratoon crop) with 
cane yield per hectare. Juice brix percent was recorded by using hydrometer assay. For juice sucrose percent, Polarimeter was used and with the help of Schmitz's table, the sucrose (pol) in juice was noted for corresponding values of brix degrees and pol reading. The juice purity percent and juice extraction percent were calculated by using the following formulae:

Juice purity percent $=\frac{\text { Juice sucrose }}{\text { Juice brix }} \times 100$

Juice extraction percent $=$

Juice weight of five cane stalks sample

Weight of five cane stalks X 100

Commercial Cane Sugar percent (CCS \%) was calculated with the help of winter crap's formula as

$$
\text { CCS percent }=\quad[S-0.4(B-S)] \times 0.73
$$

Where,

$$
\begin{aligned}
& \mathrm{S}=\text { Sucrose percent in juice; and } \\
& \mathrm{B}=\text { Corrected Brix }(\%)
\end{aligned}
$$

\section{Results and Discussion}

Analysis of variances was carried out for all the 14 characters comprising yield \& quality characters under randomized block design and the results are presented in the table 1 . It provides that there were significant differences among clones for all the characters except for juice brix. The variances (mean square) for germination percent (31.10), NMC (1179.72), millable canes (161.52), cane height (0.09), cane thickness (0 $.04)$, cane weight (0.01), purity percent (23.80), CCS percent (0.52), extraction percent (30.82) and CCS yield (1.62) were found to be highly significant. Significant values were also observed for juice sucrose (0.45) and cane yield (67.09).

\section{Mean performance of clones}

The mean performances of all clones for yield and quality characters were estimated and are presented in table 2 . The mean percentage for germination among the clones ranges from $32.21 \%$ for CoPant 3220 to $18.12 \%$ for CoPant 3219 with a general mean of $26.35 \%$. Among the clones number of tillers (thousand per hectare) ranged to a maximum 187.50 for CoS 97264 to 106.50 for CoPant 5222 with a general mean 152.25. General mean performance for NMC (thousand per hectare) was observed as 85.06 with a range of 100 for CoPant 90223 to 70.50 for CoPant 2218. The mean cane height ranged from $2.79 \mathrm{~m}$ for $\mathrm{CoS}$ 96268 to $1.82 \mathrm{~m}$ for CoK 16/05 with a general mean of $2.45 \mathrm{~m}$. Cane thickness among the clones after mean analysis was recorded in a range of $2.14 \mathrm{~cm}$ for CoPant 5224 to $1.56 \mathrm{~cm}$ for CoPant 90223 with a general mean of 1.83 $\mathrm{cm}$. Mean analysis showed that single cane weight among the clones, ranged from 1.16 $\mathrm{kg}$ for CoPant 2218 to $0.91 \mathrm{~kg}$ for CoPant 90223 with a general mean of $1.04 \mathrm{~kg}$. Juice weight of a sample of five stripped and detopped cane stalks among all the clones was ranged from $2.69 \mathrm{~kg}$ for CoPant 2218 to 1.78 $\mathrm{kg}$ for Cose 96436 , as observed by analysis with a general mean of $2.11 \mathrm{~kg}$. The mean for juice brix among the clones range from 21.45 for BO 91 to 19.35 for Co 1148 with a mean in general as 20.57. The juice sucrose percent among the clones was observed from $17.12 \%$ for CoPant 90223 to $15.31 \%$ for $\mathrm{CoJ}$ 64. The general mean was recorded as $16.37 \%$. Clones CoS 767 (17.06 \%) and CoPant 90223 has recorded higher sucrose than the checks. Mean analysis shows that the juice purity percent among clones falls in the range of $86.18 \%$ for $\operatorname{CoS} 767$ to $72.41 \%$ for CoJ 64 with a general mean of $79.67 \%$ purity. The CCS percent among the clones was observed between $11.64 \%$ for $\operatorname{CoS} 767$ to $9.48 \%$ for CoJ 64 with general mean of $10.72 \%$. 
Int.J.Curr.Microbiol.App.Sci (2020) 9(2): 740-746

Table.1 Analysis of variance for various characters in sugarcane

\begin{tabular}{|c|c|c|c|c|c|c|c|c|c|c|c|c|c|c|c|}
\hline $\begin{array}{l}\text { Source of } \\
\text { Variation }\end{array}$ & d.f. & $\begin{array}{c}\text { Germination } \\
\text { Percent }\end{array}$ & $\begin{array}{l}\text { No. of } \\
\text { tillers }\end{array}$ & $\begin{array}{l}\text { No. of } \\
\text { millable } \\
\text { canes }\end{array}$ & $\begin{array}{c}\text { Cane } \\
\text { height } \\
\text { (m) }\end{array}$ & $\begin{array}{c}\text { Cane } \\
\text { diameter } \\
(\mathbf{c m})\end{array}$ & $\begin{array}{c}\text { Single } \\
\text { cane } \\
\text { weight } \\
(\mathbf{k g})\end{array}$ & $\begin{array}{c}\text { Juice } \\
\text { weight } \\
\text { (kg) }\end{array}$ & $\begin{array}{c}\text { Juice } \\
\text { brix } \\
\%\end{array}$ & $\begin{array}{c}\text { Juice } \\
\text { sucrose } \\
\%\end{array}$ & $\begin{array}{c}\text { Juice } \\
\text { purity } \\
\%\end{array}$ & $\begin{array}{c}\text { CCS } \\
\%\end{array}$ & $\begin{array}{c}\text { Juice } \\
\text { extraction } \\
\%\end{array}$ & $\begin{array}{l}\text { Cane } \\
\text { yield } \\
\text { (t/ha) }\end{array}$ & $\begin{array}{l}\text { CCS } \\
\text { yield } \\
(t / h a)\end{array}$ \\
\hline Replications & 1 & 0.4787 & 0.250 & 16.001 & 0.0003 & 0.0009 & 0.002 & 0.017 & 0.013 & 0.027 & 1.678 & 0.037 & 0.008 & -0.048 & 0.022 \\
\hline Treatments & 17 & $31.102 * *$ & $1179.721 * *$ & $161.523 * *$ & $0.097 * *$ & $0.047 * *$ & $0.010 * *$ & $0.141 * *$ & 0.971 & $0.449 *$ & $23.804 * *$ & $0.524 * *$ & $30.826 * *$ & $67.090 *$ & $1.627 * *$ \\
\hline Error & 17 & 2.839 & 98.897 & 29.764 & 0.007 & 0.007 & 0.002 & 0.016 & 0.538 & 0.181 & 3.505 & 0.095 & 2.275 & 23.655 & 0.463 \\
\hline SE (Mean & & 1.191 & 7.031 & 3.857 & 0.061 & 0.061 & 0.035 & 0.091 & 0.518 & 0.301 & 1.323 & 0.218 & 1.066 & 3.439 & 0.481 \\
\hline CV \% & & 6.39 & 6.53 & 6.41 & 3.57 & 4.72 & 4.78 & 6.15 & 3.57 & 2.60 & 2.35 & 2.88 & 3.70 & 5.55 & 7.24 \\
\hline CD at $5 \%$ & & 3.55 & 20.98 & 11.51 & 0.18 & 0.18 & 0.10 & 0.27 & 1.55 & 0.90 & 3.95 & 0.65 & 3.18 & 10.26 & 1.44 \\
\hline
\end{tabular}

** Significant at $1 \%$ level of probability 
Table.2 Mean performance of different clones of sugarcane

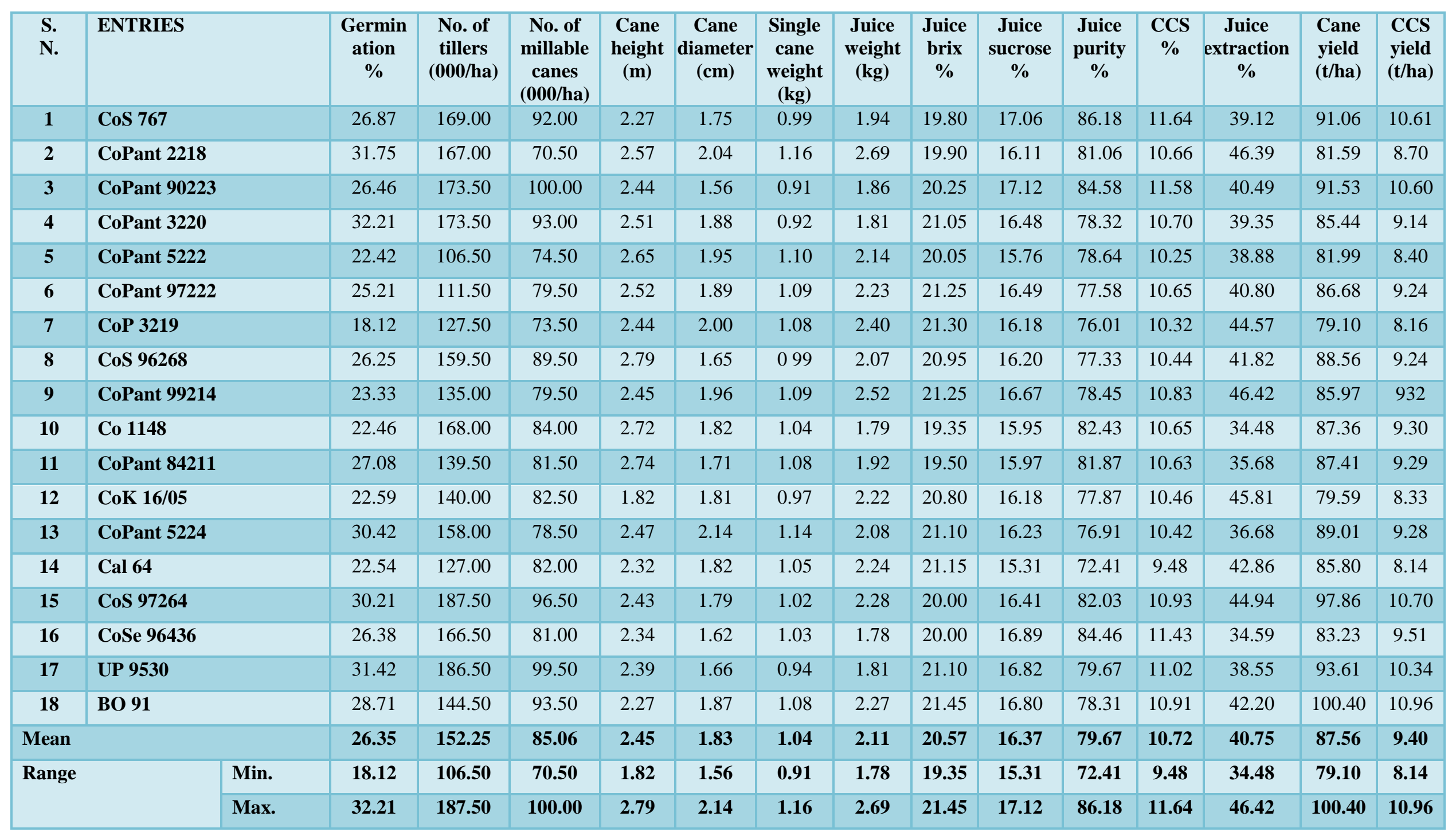


CCS percent for clones Cos 767 (11.64\%) and CoPant 90223 (11.58\%) was recorded higher than checks. Juice extraction percent among the clones was observed between $46.42 \%$ for CoPant 99214 to $34.48 \%$ for Co 1148 , with the general mean of $40.75 \%$. Mean analysis showed that among the clones cane yield in tons per hectare was higher for BO 91 (100.4 t/ha) and ranged to $79.10 \mathrm{t} / \mathrm{ha}$ for CoPant 3219, with a general mean of $87.56 \mathrm{t} / \mathrm{ha}$. None of the clones has yielded higher than the checks. The CCS yield among the clones was recorded in range of $10.96 \mathrm{t} / \mathrm{ha}$ for BO 91 to $8.14 \mathrm{t} / \mathrm{ha}$ for CoJ 64. The general mean was observed as $9.40 \mathrm{t} / \mathrm{ha}$.

Three clones namely CoS 767, CoPant 90223 and CoPant 3220 had high number of millable canes than the check CoSe 96436 and found at par with other three checks. The clones CoS 767 and CoPant 90223 had high sucrose content, purity percent and CCS percent than water logging tolerant checks CoS 97264, Cose 96436, UP 9530 and BO 91. Juice purity was also recorded high for Co 1148. Cos 767 and CoPant 90223 also had cane and CCS yield at par with the performing checks under water logging conditions. On the basis of cane and quality attributes, the clones namely, $\mathrm{CoS}$ 767 and CoPant 90223 were found performing at par as compared to checks. The breeding programme efficiency for the improvement of quantitative and quality traits depends to a large extent on magnitude of variability present in the available germplasm (Hanna et al., 1999). Goodman (1999) emphasized the importance of breeding stock and germplasm accessions by suggesting that although lines may be unpromising phenotypically but may contain untapped alleles or allelic combinations that could be utilized for plant breeding with adequate investment in conventional and marker assisted selection. Comprehensive field evaluation of these sugarcane genotypes, however, is required before these genotypes can be used in breeding programmes. The study also provides information about the performance of some of the popular sugarcane cultivars with respect to their water logging tolerance. However, detailed studies at both morphological and quality level are required to elucidate the mechanisms and the underlying genetics of this complex trait

\section{Acknowledgements}

The author acknowledges the support and valuable guide from the Advisor, Head of department of Genetics and Plant Breeding and all the supporting staff of Sugarcane Breeding Experimental Block of Norman Borlaug Crop Research Centre, Gobind Ballabh Pant University of Agriculture and Technology, Pantnagar, for conducting the experiment.

\section{References}

Carter, C.E. 1976. Excess water decreases cane and sugar yields. Proc. Am. Soc. Sug. Cane Technol., 6: 44-51.

Carter, C.E. and Floyd, J.M. 1974. Inhibition of sugarcane yields by high water table during dormant season. Proc. Am. Soc. Sug. Cane Technol., 4: 14-18.

Choi, B.H., Lee, J.T. and Chung, K.U. 1986. Influence of flooding time and duration of yield components and seed yield in growing groundnut (Arachis hupogea L). Research Report of the Rural Development Administration Crops, Korea republic, 28: 175-179.

Goodman, M.M. 1999. Broadening the genetic diversity in maize breeding by use of exotic germplasm. In: National Symposium on Onion-Garlic Production and Post Harvest management, Challenges and Strategies. Nashik. pp. 38-40.

Hanna, W., Ozias- Akins, P. and Roche, D. 1999. Apomixes and Heterosis. In: J. K. 
Coors and S. Pandey (eds.), Genetics and Exploitation of Heterosis in crops. American Society of Agronomy, Inc. Wisconsin. U.S.A. pp.335-342.

Orchard, P.W. and Jessop, R.S. 1984. The response of sorghum and sunflower to short term waterlogging I. Effects of stage development and duration of waterlogging on growth and yield. Plant
Soil, 81: 119- 132.

Rao, J.T., Natarajan, B.V. and Bhagyalakshmi, K.V. 1983. History of Sugarcane. In: Sugarcane P.4. Publ. By I.C.A.R. New Delhi.

Watson, L., Clifford, H.T. and Dalwitz, M.J. 1985. The classification of poaceae: subfamilies and super tribes. Aust. J. Bot., 33: 433-484.

\section{How to cite this article:}

Vikas Belwal and Sarfraz Ahmad. 2020. Evaluation of Sugarcane Genotypes for Morphological and Quality Traits under Water Logging Conditions. Int.J.Curr.Microbiol.App.Sci. 9(02): 740-746. doi: https://doi.org/10.20546/ijcmas.2020.902.091 